\title{
Adaptive Learning Model for Children with Learning Problem in Inclusive School
}

\author{
Aldjon Nixon Dapa \\ Special Education Study Program \\ Universitas Negeri Manado \\ Manado, Indonesia \\ aldjondapa@unima.ac.id
}

\begin{abstract}
This study aims to provide teachers with knowledge and materials in inclusive schools about adaptive learning models for children with learning difficulties. The method used was a lesson study. The subjects were 20 teachers and principals in 3 elementary schools, namely SDN II Tomohon, SD Inpres Walian and SD GMIM IV Tomohon, in Tomohon City, North Sulawesi Indonesia. The results of this study indicate that the high prevalence of children with learning disabilities in inclusive schools in Tomohon City is $8.1 \%$ of the number of students in schools that it requires serious handling. The introduction and mastery of adaptive learning models in inclusive schools become an obligation for teachers. There are learning models such as differentiated learning models and SAVI learning models, which can be implemented for children with learning difficulties. Teachers who teach in Inclusive classes are willing to create lessons that can be adapted to the needs of children in the classroom. Teaching in class with heterogeneous students is a challenge during the teacher. The ability of teachers to implement adaptive learning models will continue to be carried out if there are equal work and serious assistance from professionals, such as special education, school principals, and school supervisors.
\end{abstract}

Keywords-adaptive learning model, learning problem, inclusion school.

\section{INTRODUCTION}

The development of education, especially the education of children with special needs has actually become a thought and joint effort in accordance with the global trends in the last decade. Such conditions also become the rationale and development for universities that carry the education mission. On the other hand, education is the main instrument for the development of human resources (HR). One of the directions of the education sector focuses on improving the academic and professional abilities of education personnel so as to improve the quality of education. As the implementation of the policy, it is appropriate that programs and development activities in the education sector are directed to develop teacher professionalism. Teachers as the spearhead of education, have a strategic role in guiding, directing and developing the potential of students so that teachers are required to have educational abilities, reliable personalities who become role models of students, families, communities.
Inclusion Education is an educational service that includes all children, including children with special needs, in the same learning process. Inclusion education is different from the special education of children with disabilities, where is separated from general students inclusive education has been regulated in the Minister of National Education Regulation No. 70 of 2009. It is stated in the regulation that all schools in the province or district/city must provide inclusive education. Inclusion educators must be available at elementary, middle and high school levels.

Children with special needs are those who experience irregularities or differences from the condition of people in general ("normal") significantly so that they need special education services or children who need education services are specifically caused due to a condition. IDEA (Individuals with Disabilities Education Act) is a law in the United States that regulates the implementation of educational rights for children with special needs to determine 13 types of obstacles or disturbances that are included in the category of children with special needs, namely visual impairments, hearing impairments, emotional disturbances, speech and language impairments, intellectual barriers or mental retardation, health disorders, physical disorder, autism, multiple disabilities, developmental delay, disruption caused by accidents / brain damage, and special learning difficulties (specific learning disabilities).

Specific learning difficulties are disturbances in one or several of the basic psychological processes which include difficulties in understanding and using speech or written language, which manifests in the form of imperfections in the ability to listen, think, speak, read, write, spell or count. These limits include conditions such as perceptual disturbances and/or minimal brain disorders. The disturbance does not include learning problems caused by mental retardation, visual impairment, hearing, motor, emotional and behavioral disorders, or because of environmental, cultural or economic poverty.

Learning difficulties are indicated by the inability/difficulty in the field of language and mathematics, where this child has normal or above average intelligence, difficulties in at least one or more subjects, and has no problems or other disorders such as mental retardation that causes difficulties. Data on the number of children who have 
learning difficulties in America are presented by IDEA which has been collected during the 2000-2001 period for school-age children, so there are an estimated 2.9 million students between the ages of 6 and 21 who have learning difficulties. Meanwhile, according to Hallahan et al in [1], it was stated that about $5 \%$ of the total population of school-age children received special education because of the learning difficulties they experienced. The percentage of children classified as having learning difficulties is increasing.

In Indonesia, the data collection on the number of children with learning difficulties has never been done, but from some teachers who carry out learning in inclusive schools report that they often find children who have learning difficulties in their classrooms. Unfortunately, many teachers at schools do not understand and explore the characteristics and problems of children learning difficulties, so that the services provided to children are not appropriate and optimal learning difficulties.

Teachers in inclusive schools are required to have broad and deep knowledge and good understanding of the characteristics and problems experienced by their students who have learning difficulties. However, in reality, there are still many teachers who do not know thoroughly about learning difficulties. This can be seen from the less optimal teacher in identifying and assessing children with learning difficulties, which is less appropriate in providing learning services for students who have learning difficulties. This lack of optimization is caused by a number of things, including teachers inability to understand learning difficulties or lack of understanding of learning models for children with learning difficulties so that the teachers only allow students who have difficulty learning to learn in class, and do not try to handle them optimally and correctly.

Handling education for children with learning difficulties in Indonesia, in general, is by using an inclusive education approach. In Tomohon City, North Sulawesi province, there are several inclusive schools that provide educational services in inclusion, such as for children with learning difficulties in SDN II Tomohon, SD Inpres Walian and SD GMIM IV Tomohon. In these inclusive schools, teachers should handle children with learning difficulties by referring to learning that is tailored to children's needs and problems experienced by children with learning difficulties. However, in practice, it turns out there are still many teachers using strategies, methods, and techniques that are less structured and less systematic so that the learning done by students is less optimal.

The lack of optimal learning in children with learning disabilities in inclusive schools also appears in the teacher's lack of service in learning that is tailored to children's interests and needs. This seems based on observations and interviews conducted by researchers that most of the teachers who handle learning difficulties only provide learning by focusing only on the application of certain methods and techniques (in accordance with existing problems) whose practices are not adapted to interests, learning styles and children's thinking style. Therefore, it is often found that children are less enthusiastic, lazy and less motivated in learning.
In fact, there are several adaptive learning models for children with learning difficulties. Therefore, that it becomes the hope of all parties, especially teachers in inclusive schools, so that each model of adaptive learning can be understood, mastered and even practiced directly in the Inclusive class.

\section{METHOD}

The method used in was a lesson study (LS) method. It was conducted in two cycles, in which each cycle consists of three main activities, namely: (1) planning stage (plan), (2) implementation phase (do), and ( 3 ) the reflection (see) stage, [2]. The research subjects were 20 teachers and principals in Tomohon City inclusion school. They could provide information about learning services for children with learning disabilities in three elementary inclusion school namely SDN II Tomohon, SD Inpres Walian Elementary School, and SD GMIM IV Tomohon. The data were collected using observational sheets and then analyzed by percentage. Before the implementation of learning using adaptive learning models was done, the researchers observed the implementation of learning by teachers for students with special needs. The aspects observed were (1) methods and learning media used by teachers for students with special needs, (2) problems faced by teachers in teaching students with special needs. Based on the results of later observations carried out the implementation of learning using adaptive learning models using lesson study, where teachers who were not involved as model teachers acted as observers.

\section{RESULT AND DISCUSSION}

The prevalence of children with special needs in inclusive schools where the study was conducted reached $8.5 \%-9.1 \%$, or an average of $8.1 \%$. This amount is a calculation taken based on observations in high class (grades 4, 5, and 6) then divided by the total number of students in one school. Overall, the number of elementary school students in these three schools, the number of children with special needs is certainly enough to burden the teacher, including in children with learning difficulties.

Learning methods and media were used by the teachers during the teaching and learning processes. In general, it is seen that the method used is lecture and assignment. There is only one different method of learning namely the Rumpang method, which is found in SDN II Tomohon. Whereas for learning media found that the dominant teacher uses printed books, only a few teachers have used other reading media.

Based on an analysis of related research results and the results of discussions with the Principal, three problems were identified, namely: (1) lack of knowledge and understanding of teachers about specific learning models for children with learning difficulties, (2) teachers tend to still use common learning models when there are children with learning difficulties in their classrooms, and (3) teachers often have difficulty teaching children learning difficulties. 
TABLE I.

The PReVAlence of ChILdRen with Special NeED (CSN)

\begin{tabular}{|l|l|l|l|}
\hline \multicolumn{1}{|c|}{ School } & \multicolumn{1}{|c|}{$\begin{array}{c}\text { The } \\
\text { number } \\
\text { of } \\
\text { Students }\end{array}$} & $\begin{array}{c}\text { The } \\
\text { number } \\
\text { of CSN }\end{array}$ & $\%$ \\
\hline SDN II Tomohon & 186 & 17 & 9,1 \\
\hline SD GMIM IV Tomohon & 172 & 12 & 6,9 \\
\hline SD Inpres Walian & 94 & 8 & 8,5 \\
\hline Average & 452 & 37 & 8,1 \\
\hline
\end{tabular}

TABLE II. The Method AND Media TeACHER APPliED

\begin{tabular}{|l|l|l|}
\hline \multicolumn{1}{|c|}{ School } & \multicolumn{1}{|c|}{$\begin{array}{c}\text { Learning Method } \\
\text { Applied }\end{array}$} & Media Applied \\
\hline SDN II Tomohon & $\begin{array}{l}\text { Lecture, assignment, } \\
\text { 'rumpang' }\end{array}$ & $\begin{array}{l}\text { Printed book, } \\
\text { newspaper }\end{array}$ \\
\hline $\begin{array}{l}\text { SD GMIM IV } \\
\text { Tomohon }\end{array}$ & Lecture, assignment & Printed book \\
\hline $\begin{array}{l}\text { SD Inpres } \\
\text { Walian }\end{array}$ & Lecture, assignment & Printed book \\
\hline
\end{tabular}

The initial activity (plan) carried out was socialization of adaptive learning models for children with learning difficulties in the inclusion class. In this activity, there were approximately 20 teachers from three inclusive schools in Tomohon City aiming to get the same understanding in the selection of adaptive learning models. In this socialization activity, the amount of information was collected including what was drawn in Tables 1 and 2. In addition, the teachers also did not understand their position as teachers who would deal directly with children with learning difficulties. There are still a number of teachers asking for an explanation about children with special needs, including detailed explanations about children with learning difficulties.

The next stage is the implementation of the training of several learning models (do). In this activity, the researchers prepared instruments for several learning models, including the syntax of the learning model. Then, the teachers try to practice it with their fellow teachers. In the first cycle, the learning model that is practiced is the SAVI Learning model [3]. Whereas for the second cycle, the differentiated learning model appears that the teachers still seem to be bothered in paying attention to the syntax of learning that is quite detailed and must share the attention if there are children with learning difficulties in inclusive classes; however, they are very interested and enthusiastic to study.

After carrying out the activities, the next stage proceeds with reflection (see). In this activity, the teachers admitted that it was not easy to design adaptive learning in inclusive classes. After practicing the SAVI learning model, the teachers argued that the learning model was very appropriate for reading skills in high class. Likewise, with the differentiated learning model, the teachers argue that there is a helpful learning model in preparing alternative learning and implementing it in the classroom[4]. In addition, there is also a need for clear stages, such as the need for an assessment of the profile of children with learning difficulties, then choosing the right learning model for them.
In the case of the selection and use of learning models, the teachers tend to use the models that are not in accordance with the abilities and characteristics of children with learning difficulties. Lecture and assignment models are conventional methods and tend to be boring. Too often using this method will greatly affect the development of children's ability to study. Therefore, teachers need to apply innovative learning models, in some subjects that become problems for children with learning difficulties such as Indonesian Language, Mathematics, and Science. In accordance with the opinion of [5] that in language learning for example, at present, there are many learning models available. Even many language learning models are adopted by other fields of study. This also confirms the opinion of [6] and [7] which states that as teachers must be able to organize teaching and learning activities in the classroom through individual learning programs by paying attention to the abilities and weaknesses of each individual student. The teacher's assumptions or inappropriate teacher actions can add to the learning difficulties experienced by students [8].

In general, with various learning development activities that are often followed by teachers, giving opportunities for teachers to get to know various adaptive and innovative learning models. Especially for adaptive learning models for children with learning difficulties, such as differentiated learning models for children with learning difficulties in counting [9] SAVI learning model for children with learning difficulties in reading [10] and [11].

The adaptive learning model design is learning that is able to develop methods and approaches that are appropriate to children's needs, which can be known through the process of observation and assessment carried out both before, during, and after the learning process. The adaptive learning process is able to enrich the ability of all children without an individual being harmed. For this reason, several things need to be considered in the application of adaptive learning models in inclusive classes, including:

\section{A. Active Learning}

This approach provides assistance to children to find various learning opportunities as a vehicle for themselves to gain knowledge, for example, children are given the freedom to explore various information needed in accordance with the theme of learning, whether through games, books, magazines, newspapers, or the child's own experience.

\section{B. Negotiation of Objectives}

This is an approach that provides opportunities for each learning activity based on the interests and attention of each child. In this case, the children are observed and interviewed so that the teacher can adjust between the learning objectives and the interests of the child. Thus, this learning plan can be formulated flexibly.

\section{Demonstration, practice, and feedback}

This approach can lead to behavioral models that provide opportunities for children to imitate and also encourage 
children to imitate, use, and at the same time provide direct responses to examples of the model.

\section{Continuous evaluation}

This approach is a form of evaluation that can encourage the ability of the children's review and reflection on the learning that the teacher has done, and is able to provide an overview of how children can apply the learning. This means that this is an ongoing assessment process and does not stop and focus on the final examination, but all processes are viewed carefully so that the teacher obtains a complete picture of the child's learning conditions from beginning to end.

\section{E. Giving Support}

This approach can help children to be able to take various risks as a form of responsibility for what they do. Thus, the children have a positive sense of self-confidence because of the positive encouragement. This support must be given in various models and forms, for example appropriate learning material, friendly learning environment, accessible facilities, Government participation (educational planners), use of local culture, and support from local communities. In this way, teachers and children are expected to be helped to minimize the problems of learning and learning that they face more effectively.

\section{CONCLUSION}

Based on the results of the dedication activities that have been carried out, it can be concluded that:

- The high prevalence of children with learning difficulties in inclusive schools in Tomohon City is $8.1 \%$ of the population of students in schools, requiring serious handling.

- The introduction and mastery of adaptive learning models in inclusive schools becomes an absolute obligation for teachers. There are learning models such as differentiated learning models and SAVI learning models, which can be implemented for children with learning difficulties. It is an obligation for every teacher who teaches in inclusive classes to create learning that can adapt to the characteristics and needs of children in the classroom. Teaching in class with heterogeneous students is a challenge for teachers. If the teacher is able to do it, then it is natural that the teacher is called a professional teacher.

- The ability of teachers to implement adaptive learning models will be maintained if there is serious cooperation and assistance from professionals, such as special education lecturers, principals, and school supervisors.

\section{ACKNOWLEDGMENT}

The authors would like to thank the Institute of Research and Community Service in Manado State University for the trust and financial support so that this service can be carried out well, gratitude to the inclusive schools that have been involved during this service activity, namely SD Negeri II Tomohon, SD Inpres Walian, and SD GMIM IV Tomohon for the cooperation, and to friends and students of the special education study program, FIP Unima who have supported this community service.

\section{REFERENCES}

[1] M. Abdurahman, Pendidikan Bagi Anak Berkesulitan Belajar. Jakarta: Depdikbud dan Rineka Cipta, 2003.

[2] J. Hurd and C. Lewis, Lesson study step by step: How teacher learning communities improve instruction. Portsmouth, NH: Heinemann, 2011.

[3] A. Dapa, "Pengembangan Model Pembelajaran SAVI bagi Siswa Berkesulitan Belajar Membaca," Jurnal Pendidikan, vol. 15, no. 2, pp. 1-15, 2011.

[4] A. Dapa, "Differentiated Learning Model For Student With Reading Difficulties," Proceedings of the 9th International Conference for Science Educators and Teachers (ICSET 2017), vol. 118, Nov. 2017, pp. 976-980.

[5] S. Suyatno, Teknik Pembelajaran Bahasa dan Sastra. Surabaya: Penerbit SIC, 2004.

[6] I. Tarjiah, "Penerapan Model Pembelajaran Terdiferensiasi Untuk Meningkatkan Efektivitas Pembelajaran," Doctoral Dissertation, Universitas Negeri Jakarta, Jakarta, 2011.

[7] C. A. Tomlinson, "Differentiation of Instruction in the Elementary Grades.," ERIC Dig., vol. 7469, no. 217, pp. 1-7, 2000.

[8] I. Tarjiah, "Pengembangan Model Pembelajaran Matematika Bagi Siswa Berkesulitan Belajar Di Sekolah Dasar Inklusi," Jurnal Ilmiah VISI PPTK PAUDNI, vol. 10, no.2, pp. 102-113, Dec. 2015.

[9] D. Meier, The Accelerated Learning Handbook. New York: The McGraw-Hill Companies, Inc., 2000, pp. 42-47

[10] D. Iskandar, A. R. Hamdani, and T. Suhartini, "Implementation of Model SAVI (Somatic, Audiotory, Visualization, Intellectual) to Increase Critical Thinking Ability in Class IV of Social Science Learning on Social Issues in The Local Environtment," Journal of Education, Teaching and Learning, vol. 1, no. 1, pp. 45-50, Mar. 2016.

[11] E. D. Kurniawati, H. J. Waluyo, and S. Y. A. Slamet, (2013). "Developing a Model of Thematic Speaking Learning Materials Using SAVI Approach (Somatic, Auditory, Visual, Intellectual) In Senior High School in Sambas Regency, West Kalimantan Province, Indonesia," Online International Interdisciplinary Research Journal, vol. 3 , no. 5, pp. 444-455, 2013. 